Problems of Philosophy

General Editor: D. J. O'CONNOR

Each volume in this series provides a short introductory study of one of the main problems of philosophy. An account is given of the ways in which the given problem has been seen in the history of philosophy, and of the principal solutions which philosophers have advanced.

An important feature of the series is that in each study the language and the treatment are as simple as is compatible with a serious presentation of the philosophical difficulties. A full bibliography is included.

\author{
Published \\ Truth Alan R. White \\ Body AND Mind Keith Campbell \\ Memory Don Locke \\ In Preparation \\ Perception G. N. A. Vesey \\ Human Action G. Langford \\ Free Will D. J. O'Connor \\ Substance and Property A. P. Cavendish \\ UNIVERSALS H. Staniland \\ Explanation C. B. Wright \\ The A Priori R. W. Ashby \\ KNowledge ANd Belief R. J. Ackermann \\ Causality A. Musgrave
}


Keith Campbell was born into an academic family in Wellington, New Zealand, in 1938. He studied at the Victoria University of Wellington and at Oxford in the early 1960s and became a lecturer and then senior lecturer in the University of Melbourne (1963-65). Since 1966 he has been Senior Lecturer in Philosophy in the University of Sydney. He has contributed to Mind, Analysis, American Philosophical Quarterly, Australasian Journal of Philosophy, Politics, and to two collections of essays, The Business of Reason and Contemporary Philosophy in Australia. He is married and has three children. 


\section{BODY AND MIND}

Keith Campbell 
ISBN 978-1-349-00680-9 ISBN 978-1-349-00678-6 (eBook)

DOI 10.1007/978-1-349-00678-6

(C) Keith Campbell 1970

Softcover reprint of the hardcover 1st edition 1999 978-0-333-10043-1

All rights reserved. No part of this publication may be reproduced or transmitted, in any form or by any means, without permission.

First published in the United States 1970

First published in Great Britain 1971

Published by

THE MACMILLAN PRESS LTD

London and Basingstoke

Associated companies in New York Toronto

Dublin Melbourne Johannesburg and Madras

SBN 333100433 


\section{Contents}

1. THE MIND-BODY PROBLEM AND ITS PLACE IN PHILOSOPHY 1

(i) What the Problem Is 1

(ii) Assumptions Involved in the Mind-Body Problem

(iii) The Importance of the Mind-Body Problem

2. HOW THE MIND-BODY PROBLEM ARISES 14

(i) Four Incompatible Propositions 14

(ii) The Initial Plausibility of All Four Propositions

(i) Philosophical Objections to Spirit 41

(ii) Scientific Objections to Spirit 48

(iii) Interactionist Dualism 50

(iv) Parallelism 55

4. THE BEHAVIORIST SOLUTION 59

(i) The Behaviorist Doctrine of Mental States 
(ii) The Mind-Body Problem and the Problem of Other Minds

(iii) Behaviorism and Mental Causes

(iv) Mental Episodes

(v) The Strength of Behaviorism

(i) The Causal Theory of the Mind 77

(ii) The Significance of Mental Terms 82

(iii) Central-State Materialism 86

(iv) The Causal Theory of Mind Examined 97

(v) The Causal Theory of Mind Amended 104

(i) The Old and New Epiphenomenalisms

(ii) Double Aspect

(iii) The New Epiphenomenalism and the Mind-Body Problem

(iv) The Problem of Other Minds

(v) The Problems of Evolution and Embryonic Development

(vi) The Current State of the Mind-Body Problem 


\section{BODY AND MIND}

